\title{
LASER TREATMENT OF MACULAR RETINAL FOLDS IN LATE POSTOPERATIVE PERIOD AFTER RETINAL DETACHMENT REPAIR
}

Takhchidi KhP, Takhchidi EKh, Kasminina TA, Tebina EP $\otimes$

Pirogov Russian National Research Medical University, Moscow, Russia

\begin{abstract}
Macular retinal folds are a rare yet grave complication of surgical rhegmatogenous retinal detachment repair. Clinical symptoms vary depending on the location and severity of folding. Fold located in the periphery of the ocular fundus can be asymptomatic, but macular retinal folds cause diminished visual acuity and metamorphopsia. Currently, the most effective treatment for retinal folds is repeat surgery. Its serious disadvantage is the risk of complications in the early postoperative period, including hemophthalmia, inflammation, secondary glaucoma, cataracts, RRD recurrence, macular tears, retinal vascular occlusion, etc. The clinical case described below demonstrates the potential of combination laser therapy for the treatment of macular retinal folds based on the use of modern diagnostic and therapeutic methods.
\end{abstract}

Keywords: macular retinal folds, laser photocoagulation, rhegmatogenous retinal detachment, micropulse laser

Author contribution: Takhchidi KhP — study concept and design, manuscript editing; Takhchidi EKh — literature analysis; Tebina EP — data acquisition, manuscript preparation; Kasminina TA — laser therapy.

Compliance with ethical standards: the patient gave informed consent to laser therapy and personal data processing.

Correspondence should be addressed: Ekaterina P. Tebina

Volokolamskoe shosse, d. 30, korp. 2, Moscow, 123182, Russia; ekaterinatebina@mail.ru

Received: 19.11.2021 Accepted: 05.12.2021 Published online: 21.12.2021

DOI: $10.24075 /$ brsmu.2021.060

\section{ЛАЗЕРНОЕ ЛЕЧЕНИЕ МАКУЛЯРНОЙ РЕТИНАЛЬНОЙ СКЛАДЧАТОСТИ КАК ОСЛОЖНЕНИЯ В ОТДАЛЕННОМ ПОСЛЕОПЕРАЦИОННОМ ПЕРИОДЕ ВЕДЕНИЯ ОТСЛОЙКИ СЕТЧАТКИ}

\author{
Х. П. Тахчиди, Е. Х. Тахчиди, Т. А. Касмынина, Е. П. Тебина
}

Российский национальный исследовательский медицинский университет имени Н. И. Пирогова, Москва, Россия

\begin{abstract}
Макулярная ретинальная складчатость является редким, но серьезным осложнением после оперативного лечения регматогенной отслойки сетчатки Тяжесть проявления клинических симптомов, вызванных ретинальной складчатостью, зависит от ее расположения и степени выраженности. В случае локализации складчатости на периферии глазного дна заболевание может протекать бессимптомно, однако при расположении складок в макулярной зоне приводит к снижению остроты зрения и появлению метаморфопсий. В настоящее время наиболее эффективным методом лечения ретинальных складок является повторное оперативное лечение. Однако его недостатком является наличие рисков развития осложнений в раннем послеоперационном периоде: гемофтальма, воспалительных процессов, вторичной глаукомы, катаракты, рецидивов отслойки сетчатки, макулярных разрывов, окклюзий сосудов сетчатки и др. Представленный клинический случай демонстрирует возможность применения комбинированного лазерного лечения у пациента с осложнением в виде макулярной ретинальной складчатости, с использованием современных методов диагностики и лечения.
\end{abstract}

Ключевые слова: макулярная ретинальная складчатость, лазерная коагуляция, регматогенная отслойка сетчатки, микроимпульсное лазерное воздействие Вклад авторов: Х. П. Тахчиди — концепция и дизайн исследования, редактирование текста; Е. Х. Тахчиди — анализ литературных данных; Е. П. Тебина сбор и обработка материала, написание текста; Т. А. Касмынина - лазерное лечение пациента.

Соблюдение этических стандартов: от пациента получено согласие на лазерное лечение и обработку персональных данных.

$\triangle$ Для корреспонденции: Екатерина Павловна Тебина

Волоколамское шоссе, д. 30, корп. 2, г. Москва, 123182, Россия; ekaterinatebina@mail.ru

Статья получена: 19.11.2021 Статья принята к печати: 05.12.2021 Опубликована онлайн: 21.12.2021

DOI: 10.24075 /vrgmu.2021.060

Macular retinal folds are a rare yet grave complication of surgical rhegmatogenous retinal detachment (RRD) repair [1]. Macular folds were first described by Pavan in 1984 following a scleral buckling procedure combined with intravitreal gas tamponade. The literature on retinal folds associated with RRD surgery is scarce and mostly comprises clinical case reports. In 1991 Van Meurs et al. analyzed the outcomes of RRD surgery in 137 patients; of them, 4 (2.8\%) patients had developed retinal folds. According to a 2011 publication by Isaico et al., 3 (1.96\%) of 153 examined patients had retinal folds after surgical $\mathrm{RRD}$ repair. The primary risk factors for postoperative retinal folds include intraocular gas injection, acute RRD, large wide explants, bullous RRD with tears in the superior quadrants, transscleral drainage of subretinal fluid, and RRD extending into the macular zone [1-6].

Clinical symptoms vary depending on the location and severity of retinal folding. Macular retinal folds manifest as visual field defects, diplopia, metamorphopsia, and reduced visual acuity, whereas peripheral retinal folds can be asymptomatic [3, 6-10].

Until recently, retinal folds were classified in the literature by their location (posterior and macular), shape and orientation (arcuate), pathogenesis (compression folds), clinical features (dry) or were referred to simply as retinal folds [11].

Then, retinal fold morphology was elucidated by optical coherence tomography (OCT). Two types of retinal folds were distinguished: partial-thickness (involving the inner or outer retina) and full-thickness folds. The latter involve all layers of the retinal neuroepithelium and appear as a convex, deformed retina on OCT images. OCT features of the full-thickness retinal fold include contact between the basal segments of adjacent retinal layers, disorganized retinal architecture, structural changes in the external limiting membrane, the connecting cilium between the outer and inner photoreceptor segments, the outer nuclear layer, the outer plexiform layer and not uncommonly in the overlying layers, as well as formation of hyperreflective areas 
$[11,12]$. Inner retinal folds involve the inner retinal layer and appear on OCT as a pronounced distortion of the retinal profile presenting as internal limiting membrane to internal limiting membrane apposition. Outer retinal folds appear as multiple small vertically oriented hyperreflective lesions over the retinal pigment epithelium (RPE), extending into the outer nuclear layer [11, 12].

According to the literature, there is no unified treatment strategy for retinal folds. The outcomes also vary, from complete resolution of the fold and visual function recovery to partial regression with minimal or moderate vision recovery to severe irreversible retinal damage. In most cases, macular retinal folds persist causing irreversible loss of visual acuity and metamorphopsia [3-6, 10, 13]. Besides, patients with previously stable retinal folds are reported to develop late recurrent retinal detachment resulting from proliferative vitreoretinopathy, which in turn may be caused by retinal folds [5].

Considering the high risk of intra- and postoperative complications after repeat vitreoretinal surgery, it is important to develop a non-invasive pathogenetic treatment for retinal folds that would minimize potential damage to the sensory retina.

Currently, laser technologies are being increasingly used for treating retinal pathology. Retinal grid laser photocoagulation with spots applied in the checkerboard pattern and spaced $>1$ spot size apart is a popular technique for enhancing the structural support provided by Müller cells and improving retinal architecture by creating chorioretinal adhesions. Active and sustainable retinal tissue regeneration can be achieved through micropulse laser therapy $[14,15]$. Below we report the use of combination laser therapy for the macular retinal fold developing in the late postoperative period after surgical RRD repair.

\section{Clinical case}

In October 2020, a male patient presented with complaints of metamorphopsia and diminished visual acuity in the right eye at the Research Center of Ophthalmology, Pirogov
Russian National Research Medical University. According to his medical records, in August 2020 the patient had undergone microinvasive subtotal vitrectomy with intravitreal perfluorocarbon liquid (PFCL)/gas injection and received an intraocular lens implant for RRD in the right eye.

Once admitted to the Center, the patient underwent a comprehensive ophthalmic examination. Standard diagnostic tests included visometry for uncorrected visual acuity (UVA) and best corrected visual acuity (BCVA) and indirect ophthalmoscopy with a MaxField indirect lens (Ocular Inc.; USA). In addition, optical coherence tomography was performed using a Spectralis HRA+OCT platform (Heidelberg Engineering GmbH.; Germany).

Laser photocoagulation therapy was delivered using a VISULAS Trion work laser station (Carl Zeiss; Germany) operated at $577 \mathrm{~nm}$ wavelength.

During the initial examination the patient complained of metamorphopsia and diminished visual acuity in his right eye. UVA of the right eye (OD) was 0.05; BCVA was 0.7 for OD and 1.0 for the left eye (OS).

Ophthalmic OD biomicroscopy revealed that the anterior segment was intact and the intraocular lens was well centered. The optic disc was pale pink, with well-defined margins. A PFCL bubble was visible peripapillarily on the nasal side. Pronounced retinal folding ending with a subretinal PFCL bubble extended from the temporal optic disc margin toward the 8 o'clock plane (Fig. 1). The caliber of the retinal vessels was unchanged. Cellophane maculopathy also known as epiretinal membrane was visualized paravasally along the course of the superior and inferior temporal arcades. Laser-sealed retinal breaks were present in the upper quadrant of the peripheral

Of all OCT images of the right eye, the most informative in terms of postoperative dynamics were scan A (Fig. 2A) and the next scan B passing $250 \mu \mathrm{m}$ higher, closer to fovea (Fig. 2B).

Considering the patient's complaints, his medical history and the results of the comprehensive ophthalmic examination, the following diagnosis was established: operated RRD in the right eye complicated with macular retinal folding; epiretinal membrane; avitria; artiphakia.

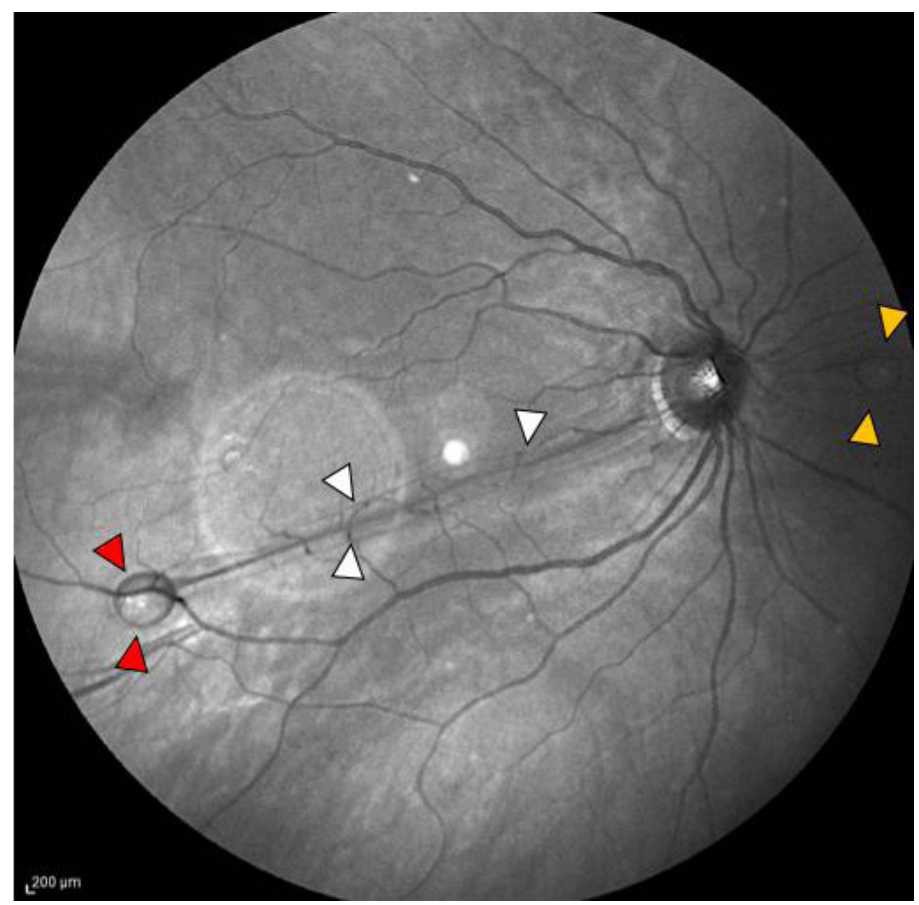

Fig. 1. The panoramic image of the right ocular fundus. A 756- $\mathrm{mm}$ PFCL bubble is visible peripapillarily on the nasal side (yellow arrow). A tight $633-\mu m-$ wide retinal fold extends from the temporal margin of the optic disc toward the 8 o'clock plane (white arrow) ending with a subretinal PFCL bubble sized $977 \mu \mathrm{m}$ (red arrow). The fold involves half of the macular zone, predominantly its lower part 


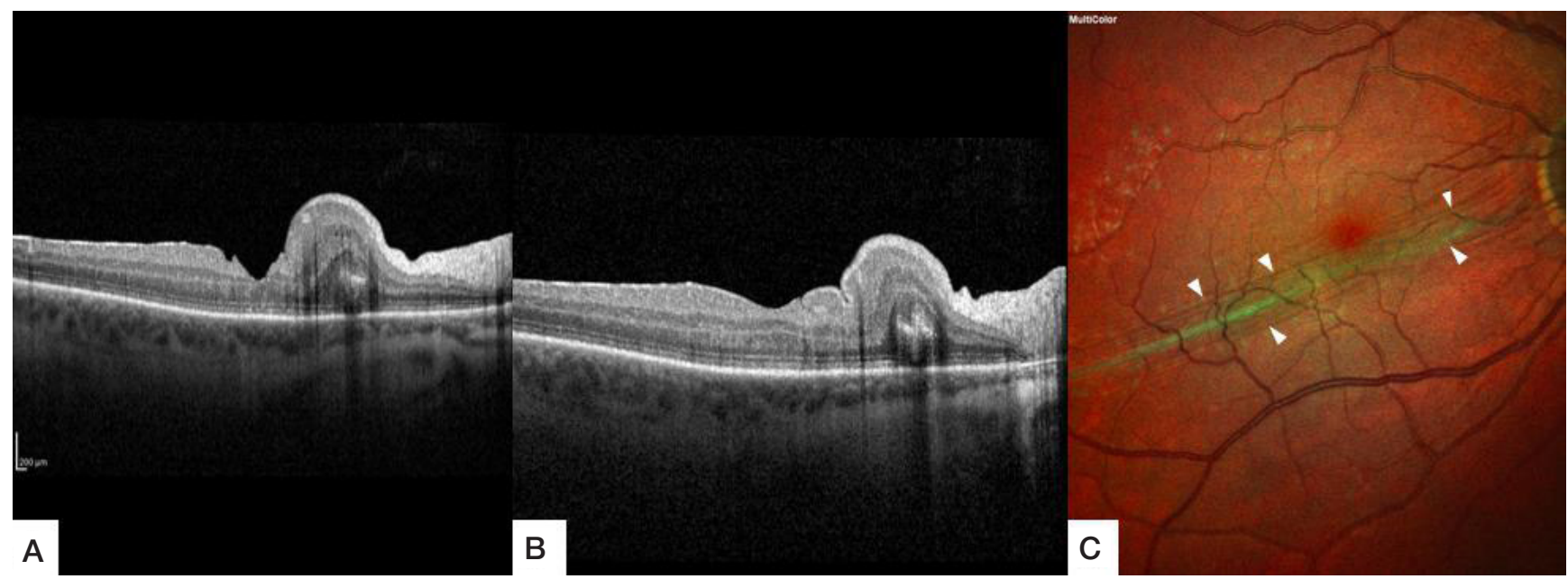

Fig. 2. Retinal spectral-domain optical coherence tomography scans of the right eye. A. The macula looks deformed, the foveal contour is normal (foveal depth: 185 $\mu \mathrm{m}$, retinal thickness in the fovea: $192 \mu \mathrm{m})$; parafoveally, on the nasal side, the retina has a convex configuration showing a dominant retinal fold up to $637 \mu \mathrm{m}$ in height, the retinal architecture looks grossly disorganized (changes involve the external limiting membrane, the connecting cilium between the inner and outer photoreceptor segments, the outer nuclear layer, and the outer plexiform layer). B. The macula is flattened; foveal depth: $106 \mu$ m, retinal thickness: $284 \mu \mathrm{m}$; a dominant full-thickness retinal fold up to $601 \mu \mathrm{m}$ in height with gross retinal structure disorganization is visualized on the nasal side, further from the foveal margin. C. A multispectral image. Pronounced 633- $\mu \mathrm{m}$-wide retinal folding extends from the temporal margin of the optic disc toward the 8 o'clock plane (white arrows)

In December 2020, a decision was made to perform laser microsurgery on the patient in order to restore the architecture of the macular zone, flatten the folds, and improve the morphology and function of the retina. The combination treatment was delivered in several steps. In the first step, the patient underwent grid laser photocoagulation. The burns were applied along the course of the retinal fold and under it in the checkerboard pattern in 3 to 4 rows depending on the severity of the fold; the avascular zone was avoided. The laser workstation was operated at the lowest possible settings to ensure the lowest intensity of coagulation: power $50 \mathrm{~mW}$, pulse duration $0.05 \mathrm{~s}$, spot diameter $100 \mu \mathrm{m}$, wavelength $577 \mathrm{~nm}$, spacing $150 \mu \mathrm{m}$. Single laser spots were applied paramacularly along the upper edge of the macula. Additionally, laser coagulation was performed on the epiretinal membrane along the course of the superior and inferior temporal vascular arcades. In the second step, the patient received 3 sessions of micropulse laser therapy (wavelength $577 \mathrm{~nm}$, burst duration $30 \mathrm{~ms}$, micropulse duration $50 \mu$ s, pulse ratio $4.7 \%$, spot diameter $100 \mu \mathrm{m}$, power $50 \mathrm{~mW}$.

Two months after surgery, the comprehensive ophthalmic examination revealed a slight improvement, although no significant morphological and functional changes were observed.
Four months after the intervention, the patient reported a significant reduction of metamorphopsia. His UVA and BCVA had improved to 0.2 and 0.7 , respectively. Ophthalmic biomicroscopy of the right eye revealed the intact anterior segment and the well-centered intraocular lens. The fold in the central zone had flattened and was now $921 \mu \mathrm{m}$ wide (Fig. 3B). Paramacularly and along the retinal fold, weakly pigmented coagulation spots were visible. The caliber of the retinal vessels was unchanged. Paravasally, weakly pigmented coagulation spots were present in the epiretinal membrane area. Changes in the retina can be clearly seen on the follow-up OCT scans (Fig. 3A, B).

Six months later on another follow-up examination the patient reported the absence of metamorphopsias in the right eye; UVA: 0.2; BCVA: 0.7. On ophthalmic biomicrosopy the anterior segment was intact, the intraocular lens was wellcentered. The optic disc was pale pink, with well-defined margins. The retinal folds had unfolded, the dominant retinal fold was not visualized. A slight undulation (up to $1.371 \mu \mathrm{m}$ in width) was visualized on the retinal surface where retinal folding had been previously observed (Fig. 4B). Weakly pigmented coagulations spots were present in the epiretinal membrane area, except for the avascular zone. Changes in the retina can be clearly seen on the follow-up OCT scans (Fig. 4A, B).

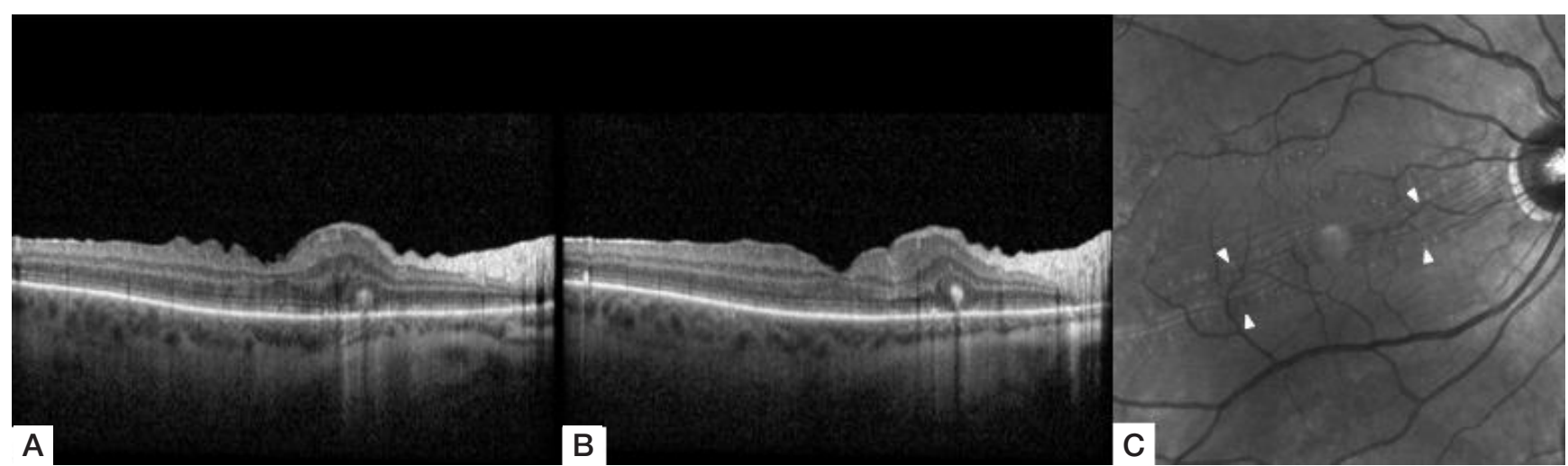

Fig. 3. Retinal spectral-domain optical coherence tomography scans of the right eye. A. The macular profile is restored; the fovea is flattened: foveal depth 134 um, retinal thickness in the fovea $240 \mu \mathrm{m}$; parafoveally on the nasal side, the retinal fold has diminished in height from 637 to $487 \mu \mathrm{m}$; the structural organization of the retinal layers appears partially restored; microfolds are visualized in the inner retinal layers paramacularly on the temporal side. B. The foveal contour is clear; foveal depth has increased to $142 \mu \mathrm{m}$, retinal thickness in the fovea has decreased to $243 \mu \mathrm{m}$; parafoveally on the nasal side, the retinal fold has diminished in height from 601 to $473 \mu \mathrm{m}$, the structural organization of the retinal layers looks partially restored. C. Infrared image. In the central zone, the folds have become less pronounced and flattened to $921 \mu \mathrm{m}$ in width (white arrow) 


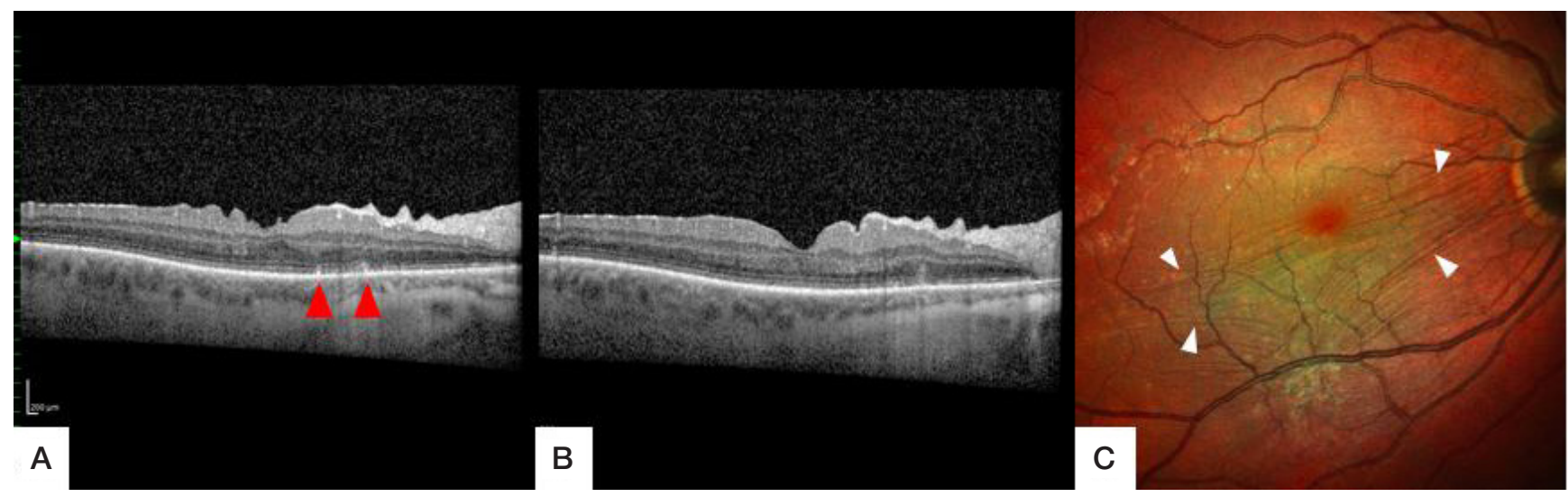

Fig. 4. Retinal spectral-domain optical coherence tomography scans of the right eye. A. The macular profile is restored, the fovea is flattened; foveal depth has decreased to $124 \mu \mathrm{m}$, retinal thickness in the fovea has increased to $273 \mu \mathrm{m}$; paramacularly, on the nasal side, intraretinal coagulation spots are visible at the RPE level (red arrow). B The macular profile is restored, the fovea has a clear contour; foveal depth: $160 \mu \mathrm{m}$, retinal thickness in the fovea: $224 \mu \mathrm{m}$, the structural organization of the retinal layers is restored; paramacularly on the nasal side microfolds are visible in the inner retinal layers. C. A multispectral image: the retinal folds have unfolded (white arrow), weakly pigmented coagulation spots are visible in the macular zone, except for the avascular area, and in the epiretinal membrane area.

\section{Clinical case discussion}

Retinal folds are a clinically important complication of surgical RRD repair. Few attempts have been reported to surgically treat retinal folds, including macular folds of different etiology $[2,16,18]$. There is no clear guidance on the timeframe and indications for repeat surgery. Experiments conducted in vivo have demonstrated that apoptosis of the photoreceptor layer and thinning of the outer nuclear layer start a week after macular translocation [18].

Repeat surgery is often delayed because retinal folds can be diagnosed no sooner than gas injected in the vitreous cavity is reabsorbed. Another reason is the risk of complications in the early postoperative period, including hemophthalmia, inflammation, secondary glaucoma, cataracts, RRD recurrence, macular tears, retinal vascular occlusion, etc. [11, 17, 19].

This study describes an alternative to vitreoretinal surgery: a combination laser therapy involving 2 interventions with different mechanisms of action. The proposed treatment method has indisputable advantages like non-invasiveness, low injury rate, and lack of serious complications or adverse effects. Due to the gradual topographically directed effect of grid laser photocoagulation, we were able to unfold the retina, restore the position of the macula and its functional and morphological characteristics. Paramacular tissues (the dominant retinal fold) flattened out, and retinal thickness and structural organization were recovered. The macular profile shifted to its normal microtopographic position, becoming more clearly visible on
OCT scan B (Fig. 3B); foveal depth and width also normalized. The patient's metamorphopsia (distorted vision) resolved, his uncorrected visual acuity and the ability to use binocular vision improved. In addition, micropulse laser therapy prolonged tissue regeneration.

Summing up, the coagulation effect of laser energy applied locally to achieve controlled retinal stretching causes shifting of retinal microlayers, reorganizing the architecture of the macular zone. Low-dose exposure of the affected retinal zones to micropulse laser energy activates prolonged regeneration.

The proposed method produced pronounced morphofunctional effects on macular retinal folding, which develops in the late postoperative period after retinal detachment repair.

\section{CONCLUSION}

The proposed combination laser treatment of macular folds developing in the late postoperative period after $R R D$ repair significantly improved the morphofunctional characteristics of the eye. The application of transpupillary laser surgery to ophthalmological practice broadens the arsenal of methods for noninvasive correction of RRD associated with macular retinal folds

The study demonstrates the potential of laser microsurgery (at the micron level) for correcting the damaged microtopography and microarchitecture of the macular retina, ensuring recovery of normal functions of the eye.

\section{References}

1. Pavan PR. Retinal fold in macula following intraocular gas: an avoidable complication of retinal detachment surgery. Arch Ophthalmol. 1984; 102 (1): 83-84

2. Gruener AM, Lee RMH, Kourtis N, Herbert L. Surgical repair of macular fold after vitrectomy for bullous rhegmatogenous retinal detachment. Retina. 2013; 33 (4): 894-7.

3. Larrison WI, Frederick AR Jr, Peterson TJ, Topping TM. Posterior retinal folds following vitreoretinal surgery. Arch Ophthalmol. 1993; 111 (5): $621-5$.

4. Lewen RM, Lyon CE, Diamond JG. Scleral buckling with intraocular air injection complicated by arcuate retinal folds. Arch Ophthalmol. 1987; 105 (9): 1212-4.

5. van Meurs JC, Humalda D, Mertens DA, Peperkamp E. Retinal folds

through the macula. Doc Ophthalmol. 1991;78 (3-4): 335-40.

6. Heimann H, Bopp S. Retinal Folds following Retinal Detachment Surgery. Ophthalmologica. 2011; 226 (1): 18-26.

7. Trinh L, Glacet-Bernard A, Colasse-Marthelot V, Leynaud JL, Soubrane G. Macular fold following retinal detachment surgery. J Fr Ophtalmol. 2006; 29 (9): 995-9.

8. El-Amir AN, Every S, Patel CK. Repair of macular fold following retinal detachment surgery. Clin Experiment Ophthalmol. 2007; 35 (9): 791-2

9. Herbert EN, Groenewald C, Wong D. Treatment of retinal folds using a modified macula relocation technique with perfluorohexyloctane tamponade. Br J Ophthalmol. 2003; 87 (7): 921-2. 
10. Ruiz-Moreno JM, Montero JA. Sliding macular fold following retinal detachment surgery. Graefes Arch Clin Exp Ophthalmol. 2011; 249 (2): 301-3.

11. R Rishi Gupta, Douglas S M laboni, Mark E Seamone, David Sarraf. Inner, outer, and full thickness retinal folds following rhegmatogenous retinal detachment repair: A Review. Surv Ophthalmol. 2019; 64 (2): 135-61.

12. Stolyarenko GE, Savostyanova NV, Doroshenko D, Salahutdinov VK. Makuljarnye skladki posle hirurgii otslojki setchatki c polnym ee prileganiem. Sovremennye tehnologii v oftal'mologii. 2020 (1): 257-63. Russian

13. Pierro L, Sadda SR, Gagliardi M, Mantovani E, de Benedetto U., Codenotti M, Bandello F. SD OCT features of dry arcuate longstanding retinal folds. Eur J Ophthalmol. 2011; 21 (6): 215-7.

14. Fedoruk NA, Fedorov AA, Bolshunov AV. Morfologicheskie i gistohimicheskie osobennosti subporogovogo lazernogo vozdeïstvija na struktury horioretinal'nogo kompleksa. Vestnik oftal'mologii. 2013; (5): 73-81. Russian.

\section{Литература}

1. Pavan PR. Retinal fold in macula following intraocular gas: an avoidable complication of retinal detachment surgery. Arch Ophthalmol. 1984; 102 (1): 83-84.

2. Gruener AM, Lee RMH, Kourtis N, Herbert L. Surgical repair of macular fold after vitrectomy for bullous rhegmatogenous retina detachment. Retina. 2013; 33 (4): 894-7.

3. Larrison WI, Frederick AR Jr, Peterson TJ, Topping TM. Posterior retinal folds following vitreoretinal surgery. Arch Ophthalmol. 1993; 111 (5): 621-5.

4. Lewen RM, Lyon CE, Diamond JG. Scleral buckling with intraocular air injection complicated by arcuate retinal folds. Arch Ophthalmol. 1987; 105 (9): 1212-4.

5. van Meurs JC, Humalda D, Mertens DA, Peperkamp E. Retinal folds through the macula. Doc Ophthalmol. 1991;78 (3-4): 335-40.

6. Heimann H, Bopp S. Retinal Folds following Retinal Detachment Surgery. Ophthalmologica. 2011; 226 (1): 18-26.

7. Trinh L, Glacet-Bernard A, Colasse-Marthelot V, Leynaud JL, Soubrane G. Macular fold following retinal detachment surgery. J Fr Ophtalmol. 2006; 29 (9): 995-9.

8. El-Amir AN, Every S, Patel CK. Repair of macular fold following retinal detachment surgery. Clin Experiment Ophthalmol. 2007 35 (9): 791-2.

9. Herbert EN, Groenewald C, Wong D. Treatment of retinal folds using a modified macula relocation technique with perfluorohexyloctane tamponade. Br J Ophthalmol. 2003; 87 (7): 921-2.

10. Ruiz-Moreno JM, Montero JA. Sliding macular fold following retinal detachment surgery. Graefes Arch Clin Exp Ophthalmol. 2011; 249 (2): 301-3.

11. R Rishi Gupta, Douglas S M laboni, Mark E Seamone, David Sarraf. Inner, outer, and full thickness retinal folds following rhegmatogenous retinal detachment repair: A Review. Surv
15. Zheltov GI, Romanov GS, Romanov OG, Ivanova EV. Selektivnoe dejstvie lazernyh impul'sov na retinal'nyj pigmentnyj jepitelij. Fizicheskie osnovy. Novoe v oftal'mologii. 2012; (3): 37. Russian.

16. Ahn SJ, Woo SJ, Ahn J, Park KH. Spontaneous resolution of macular fold following retinal reattachment: morphologic features on SD-OCT. Ophthalmic Surg Lasers Imaging. 2011; 42 Online: e81-83.

17. Barale $\mathrm{P}$, Mora $\mathrm{P}$, Errera $\mathrm{M}-\mathrm{H}$, Ores R, Paques M, Sahel J-A. Treatment of macular folds complicating retinal detachment surgery using air for retinal unfolding. Retin Cases Br Reports. 2018; 12 (3): 228-30.

18. Hayashi A, Usui S, Kawaguchi K, et al. Retinal changes after retinal translocation surgery with scleral imbrication in dog eyes. Investig Ophthalmol Vis Sci. 2000; 41 (13): 4288-92.

19. Benson SE, Schlottmann PG, Bunce C, Xing W, Charteris DG. Optical Coherence Tomography Analysis of the Macula after Vitrectomy Surgery for Retinal Detachment. Ophthalmology. 2006; 113 (7): 1179-83.

Ophthalmol. 2019; 64 (2): 135-61.

12. Столяренко Г. Е., Савостьянова Н. В., Дорошенко Д., Салахутдинов В. К. Макулярные складки после хирургии отслойки сетчатки с полным ее прилеганием. Современные технологии в офтальмологии. 2020 (1): 257-63.

13. Pierro L, Sadda SR, Gagliardi M, Mantovani E, de Benedetto U., Codenotti M, Bandello F. SD OCT features of dry arcuate longstanding retinal folds. Eur J Ophthalmol. 2011; 21 (6): 215-7.

14. Федорук Н. А., Федоров А. А., Большунов А. В. Морфологические и гистохимические особенности субпорогового лазерного воздействия на структуры хориоретинального комплекса. Вестник офтальмологии. 2013; (5): 73-81.

15. Желтов Г. И., Романов Г. С., Романов О. Г., Иванова Е. В. Селективное действие лазерных импульсов на ретинальный пигментный эпителий. Физические основы. Новое в офтальмологии. 2012; (3): 37.

16. Ahn SJ, Woo SJ, Ahn J, Park KH. Spontaneous resolution of macular fold following retinal reattachment: morphologic features on SD-OCT. Ophthalmic Surg Lasers Imaging. 2011; 42 Online: e81-83.

17. Barale P, Mora P, Errera M-H, Ores R, Paques M, Sahel J-A. Treatment of macular folds complicating retinal detachment surgery using air for retinal unfolding. Retin Cases $\mathrm{Br}$ Reports. 2018; 12 (3): 228-30.

18. Hayashi A, Usui S, Kawaguchi K, et al. Retinal changes after retinal translocation surgery with scleral imbrication in dog eyes. Investig Ophthalmol Vis Sci. 2000; 41 (13): 4288-92.

19. Benson SE, Schlottmann PG, Bunce C, Xing W, Charteris DG. Optical Coherence Tomography Analysis of the Macula after Vitrectomy Surgery for Retinal Detachment. Ophthalmology. 2006; 113 (7): 1179-83. 